\title{
DNA VARIATION IN THE GENUS RANUNCULUS
}

\author{
J. B. SMITH and M. D. BENNETT \\ Plant Breeding Institute, Maris Lane, Trumpington, Cambridge
}

Received 15.ii.75

\begin{abstract}
SUMMARY
DNA amounts for 19 species in the genus Ranunculus were estimated by Feulgen photometry. $4 C$ values showed an approximately 13 -fold range from $7.9 \mathrm{pg}$ in $R$. lateriflorus to 103.2 in $R$. lingua; however, the ranges for diploids alone and tetraploids alone were both only about 5 -fold. The minimum and maximum values for tetraploid species were almost exactly double the corresponding values for diploids. The mean and range of DNA amounts for annual species was significantly lower than for perennials in comparisons at both the diploid and tetraploid levels. The present results are compared first with DNA amounts for species in the family Ranunculaceae published previously, and second with results from previous studies of DNA amounts in annual and perennial species.
\end{abstract}

\section{INTRODUCTION}

INTERSPECIFIC variation in $4 C$ nuclear DNA amounts has been investigated in various angiosperm genera or tribes including: Aegilops (Furuta, 1970), Anthemideae (Nagl, 1974), Allium (Jones and Rees, 1968), Avena (Bullen and Rees, 1972), Brassica (Verma and Rees, 1974), Fritillaria (Bennett, 1972), Gossypium (Edwards, Endrizzi and Stein, 1974), Hordeum (Bennett and Smith, 1971), Lathyrus (Rees and Hazarika, 1969), Lolium (Jones and Rees, 1967), Nicotiana (Narayan and Rees, 1974), Phalaris (Kadir, 1974), Phaseolus (Ayonoadu, 1974), Sorghum (Paroda and Rees, 1971), Tulipa (Southern, 1967) and Vicia (Chooi, 1971). Within most groups, considerable interspecific variation in DNA amount was found between closely related species at the same ploidy level. However, in Hordeum no significant interspecific variation was found (Bennett and Smith, 1971).

Bennett (1972) demonstrated a positive relationship between nuclear DNA amount and life-cycle time in a large sample of unrelated herbaceous higher plant species. For example, in diploid monocots the mean (18.5 pg) and range (4.3-28.4 pg) of DNA amounts for annual species was much lower than the mean (97.2) and range (4.7-295 pg) for perennial species. Similar results have also been noted in comparisons of annual and perennial species in a single genus, notably in Lathyrus (Rees and Hazarika, 1969) and in Vicia (Chooi, 1971).

In a previous study of 22 perennial diploid species from six genera of the Ranunculaceae (Rothfels et al., 1966) the results showed a large range of chromosome size and a 40 -fold range of $4 C$ DNA amounts. The genus Ranunculus, which was not included in the previous study (loc. cit.), contains both annual and perennial species with two basic numbers $(x=7,8)$; and both diploid and polyploid species are common. Our preliminary investigations showed a considerable range of chromosome sizes within both diploid and tetraploid species. We decided, therefore, to investigate DNA amounts in the genus Ranunculus, first to extend the knowledge of DNA 
variation in the Ranunculaceae (supposedly a primitive family among the dicots), and second, to compare DNA amounts in related annual and perennial species in this genus.

\section{TABLE 1}

The 4C DNA amount per nucleus and the mean DNA amount per chromosome in 19 Ranunculus species together with the life-cycle types

Ploidy and basic number
Species

Diploid

(i) $x=7 \quad$ chius DC.

acris $\mathbf{L}$.

(ii) $x=8 \quad$ laterifolius DC.

\section{hederaceus $\mathbf{L}$. \\ sardous Crantz. \\ aconitiflorus $\mathbf{L}$.}

ssp. plantanifolius

bulbosus L.

cortusifolius Willd.

ficaria $\mathbf{L}$.

\section{Triploid}

$x=8$

ficaria L.

\section{Tetraploid}

$x=8$

scleratus $\mathbf{L}$.
trichophyllus Chaix
arvensis $\mathbf{L}$.
flammula L.
flabellatus Desf.
auricomus L.
repens L.
ficaria L.

\section{Pentaploid}

$x=8$

\section{Hexaploid}

$x=8$

muricatus $\mathbf{L}$.

lingua $\mathbf{L}$.
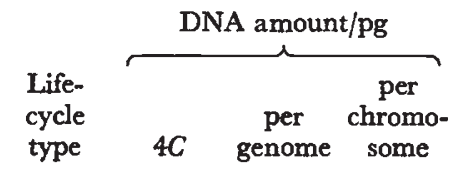

Origin

$\begin{array}{rrrr}18.13 & 9.06 & 1.30 & \begin{array}{c}\text { Royal Botanic Gardens, } \\ \text { Kew } \\ \text { Knapwell, Cambridge- }\end{array} \\ \text { shire }\end{array}$

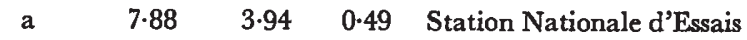
de Semenses, Versailles, France

Keston, Kent

$\begin{array}{lllll}\text { a } & 13.35 & 6.67 & 0.83 & \text { Hastings, Sussex }\end{array}$

p $\quad 17.21 \quad 8.60 \quad 1.08$ Cambridge Botanic Gardens

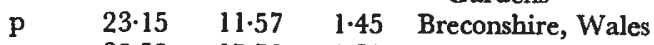

p $\quad 35.52 \quad 17.76 \quad 2.22$ Royal Botanic Gardens,

p $\quad 38.40 \quad 19 \cdot 20 \quad 2.40 \quad$ Trumpington, Cambridgeshire

p $\quad 58.30 \quad 19.43 \quad 2.43 \quad$ Trumpington, Cambridgeshire

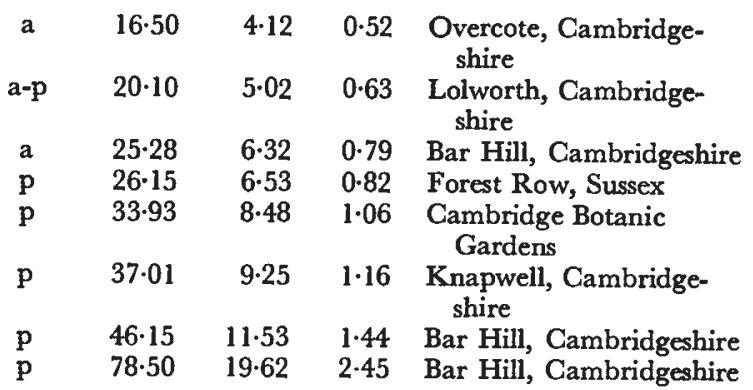

a $\quad 21 \cdot 1$

a

$47 \cdot 75$

p $\quad 103 \cdot 20$
$4 \cdot 23$

0.53

Cambridge Botanic Gardens

7.95 0.99 Cambridge Botanic Gardens

6.45 $\quad 0.81$ Scotsdale Nursery, Cambridgeshire

\footnotetext{
* This species has recently been placed in the closely related genus Ceratocephalus.
} 


\section{Materials AND methods}

The species used in the present work are listed in table 1 which also gives the ploidy level, basic number, life-history type, and $4 C$ DNA amount for each species. Native British species were collected from various localities in England and Wales, while non-British species were obtained as seeds or plants from several Botanic Gardens (table 1).

Plants were grown in a glasshouse. Actively growing roots were fixed in $1: 3$ acetic acid-ethyl alcohol for between 2 and 24 hours. Fixed roottips were prepared for microdensitometry using a method slightly modified from that of McLeish and Sunderland (1961) and squashed in distilled water. Nuclear DNA amount was estimated photometrically at $560 \mathrm{~nm}$ using a Barr and Stroud type GN2 integrating microdensitometer. For each species measurements were made using ten prophase nuclei on each of three separate slides (replicates). Each slide was prepared from a single root-tip taken from a separate plant. Thus, estimates of the $4 C$ DNA amount for each species expressed in relative absorption units (r.a.u.) were obtained as the mean of readings for 30 nuclei. These estimates were converted to absolute units by comparison with results for prophase nuclei from root-tips of Pisum sativum L. cv. " Minerva Maple" which was assumed to have a $4 C$ DNA amount of 20 picograms (Ingle and Sinclair, 1972).

\section{REsults}

The present results for Ranunculus show, as expected, considerable interspecific variation in $4 C$ DNA amount. Overall, the 19 species examined show an approximately 13-fold range of DNA amounts (table 1) from 7.88 $\mathrm{pg}$ in $R$. lateriflorus to $103.2 \mathrm{pg}$ in $R$. lingua. Both diploid species (from 7.88 $\mathrm{pg}$ in $R$. lateriflorus to $38.4 \mathrm{pg}$ in $R$. ficaria) and tetraploid species (from 16.5 $\mathrm{pg}$ in $R$. scleratus to $78.5 \mathrm{pg}$ in $R$. ficaria) showed approximately 5 -fold ranges of DNA amounts.

In species with a basic number of 8 , the minimum and maximum DNA values for tetraploid species (16.5 and $78.0 \mathrm{pg}$ ) are almost exactly double the minimum and maximum values for diploid species (7.88 and $34.5 \mathrm{pg}$ ). This fact might be interpreted as suggesting that little variation in DNA amount has occurred in tetraploid species subsequent to their formation from parent diploid species with consequent doubling of the nuclear DNA content. Such is obviously the case in $R$. ficaria, since diploid, triploid and tetraploid forms had a virtually constant DNA amount per genome.

Comparison of species which are either annuals or have annual forms with perennial species shows a significantly higher $(P<0.001)$ mean DNA content in the latter than in the former (table 2). For instance, the mean DNA amount for diploid perennials $(27.26 \mathrm{pg})$ is more than twice that for diploid annuals (12.03 pg). Similarly, the mean for tetraploid perennials (44.35) was more than twice that for tetraploid annuals (20.63). Moreover, the ranges of values for annual and perennial species did not overlap for comparisons of either diploid species alone, or tetraploid species alone (table 2).

As the basic number is almost constant $(x=7$ or 8$)$ in the 19 species examined, it follows that variation in $4 C$ DNA amount within a ploidy level is reflected by similar variation in mean DNA content per chromosome. 
Thus, mean DNA content per chromosome in diploids shows an approximately 5-fold range from $0.49 \mathrm{pg}$ in $R$. lateriflorus to $2.40 \mathrm{pg}$ in $R$. ficaria, and the range of values for tetraploids are virtually identical. The mean DNA content per chromosome in the two species with basic number $(x=7)$ falls within the range for species with basic number $(x=8)$. The DNA per chromosome values in Ranunculus species $(0 \cdot 49-2.45 \mathrm{pg})$ fall well within the range for other species in the Ranunculaceae, i.e. from about $0.1 \mathrm{pg}$ in an Aquilegia hybrid to about $5.3 \mathrm{pg}$ in Anemone tetrasepala.

TABle 2

The mean and range of 4C. DNA amounts (in pg) in annual and perennial Ranunculus species

\begin{tabular}{|c|c|c|c|c|}
\hline \multirow[b]{2}{*}{ Ploidy level } & \multicolumn{2}{|c|}{ Annuals } & \multicolumn{2}{|c|}{ Perennials } \\
\hline & Mean & Range & Mean & Range \\
\hline $\begin{array}{l}\text { Diploids } \quad(x=7,8) \\
\text { Tetraploids }(x=8)\end{array}$ & $\begin{array}{l}12 \cdot 03(4) \\
20 \cdot 63(3)\end{array}$ & $\begin{array}{r}7 \cdot 88-13 \cdot 35 \\
16 \cdot 50-25 \cdot 28\end{array}$ & $\begin{array}{l}27 \cdot 26(5) \\
44 \cdot 35(5)\end{array}$ & $\begin{array}{l}17 \cdot 21-34 \cdot 40 \\
26 \cdot 15-78 \cdot 50\end{array}$ \\
\hline
\end{tabular}

$\mathcal{N} . B$. - The number of species in each class is given in brackets after the mean. The two species with a range of life-cycle types are classified according to their shortest life-cycle type.

It is interesting to note that the mean DNA content per chromosome and the DNA content per genome in the three higher polyploid species, although falling within the range of values for these characters found in diploid species, nevertheless all fall at the lower end of the respective ranges. The $4 C$ DNA amount for $R$. lingua $(103.2 \mathrm{pg})$ approaches that of the highest known value for a dicot species (i.e. $142 \mathrm{pg}$ for Chrysanthemum lacustre), and is the second highest value known for such species. Thus, if $R$. lingua had chromosomes as large as $R$. ficaria its $4 C$ DNA amount would be about $250 \mathrm{pg}$, which is considerably higher than the highest value for a dicot species found hitherto.

\section{Discussion}

The present results for 19 species in the genus Ranunculus agree with those of Rothfels et al. (1966) for 22 species in six other genera of the Ranunculaceae in showing considerable differences in the mean DNA content per genome. DNA amounts for diploid species in the present study $(7 \cdot 88-34 \cdot 40$ pg) all fall within the range for diploid species reported by Rothfels et al. $(1.87-71.0 \mathrm{pg})$. The overall range of values for species in six genera of the Ranunculaceae was about 40 -fold, but, the largest range for a single genus, namely Anemone, was about 2.5-fold (Rothfels et al., 1966). Thus, although the present range of value for diploid Ranunculus species is smaller than the overall range reported previously for species in the Ranunculaceae, it exceeds that reported previously for a single genus.

Rothfels et al. (1966) found that values for diploid species did not form a continuous series but appeared to be "quantised ", that is, they appeared to fit an arithmetic progression. They interpreted this result as evidence of differential polynemy. Sparrow and Nauman (1973) presented evidence showing that DNA per genome values tend to fall close to a geometric doubling series in comparisons of widely different organisms, including bacteria, the Gymnosperms, the Gramineae and, interestingly, the Ranunculaceae. They suggested that a process involving the tandem duplication 
of all or most of the DNA strand in a chromosome occurs with a low frequency and randomly with time, thus giving the geometric doubling series noted for species DNA amounts in various organisms. They called the suggested mechanism, though admittedly unknown, responsible for such overall duplications of genetic material, "cryptopolyploidy". Unfortunately, Sparrow and Nauman have not published the names or the DNA amounts of the species in the Ranunculaceae which they examined.

TABLE 3

The mean and range of $4 \mathrm{C} D \mathcal{N} A$ amounts in annuals and perennials in six groups of higher plant species

\begin{tabular}{|c|c|c|c|c|c|}
\hline \multirow[b]{2}{*}{ Genus or tribe } & \multicolumn{2}{|c|}{ Annuals } & \multicolumn{2}{|c|}{ Perennials } & \multirow[b]{2}{*}{ Reference } \\
\hline & Mean & Range & Mean & Range & \\
\hline Phalaris & $15 \cdot 38 \quad(3)$ & $8 \cdot 17-18 \cdot 74$ & $11.00(2)$ & $6 \cdot 71-15 \cdot 28$ & Kadir, 1974 \\
\hline Anthemideae & $11.43 \quad(5)$ & $4 \cdot 05-16 \cdot 92$ & $9.02(3)$ & $7 \cdot 28-12 \cdot 42$ & Nagl, 1974 \\
\hline Lolium & 26.53 (3) & $25 \cdot 00-27 \cdot 40$ & $19.54(3)$ & $19 \cdot 20-19 \cdot 80$ & $\begin{array}{l}\text { Jones and Rees, } \\
1969\end{array}$ \\
\hline Ranunculus & $12 \cdot 03 \quad(4)$ & $7 \cdot 88-13 \cdot 35$ & $27 \cdot 26(5)$ & $17 \cdot 21-38 \cdot 40$ & This paper \\
\hline Cracca & $15 \cdot 30 \quad(6)$ & $8 \cdot 97-26 \cdot 70$ & $24 \cdot 62(9)$ & $17 \cdot 71-39 \cdot 91$ & Chooi, 1971 \\
\hline Lathyrus & $29 \cdot 31(12)$ & $17 \cdot 90-40 \cdot 20$ & $37 \cdot 32(6)$ & $31 \cdot 10-45 \cdot 90$ & $\begin{array}{l}\text { Rees and Hazarika, } \\
1969\end{array}$ \\
\hline
\end{tabular}

$\mathcal{N} . B .-$ The number of species of each life-cycle type is given in brackets after the mean.

Consequently, no direct comparison between their data and the present results is possible. It would be presumptious to comment in detail on the suggestions regarding chromosome structure made by Rothfels et al. (1966) or Sparrow and Nauman (1973) in view of the limited number of new DNA amounts for species in the Ranunculaceae given in the present work.

Comparisons of unrelated higher diploid plant species have shown that the rate of development during various cell processes (including mitotic cycle in somatic cells, meiosis and pollen maturation) is inversely related to species DNA amount (for reviews see Bennett 1972, 1973). It has been suggested that the effects of an increase in DNA amount, slowing development at various stages of the life-cycle, are together causally responsible for determining an increased generation time (Commoner, 1964; Bennett, 1972). As a test of this hypothesis Bennett (1972) showed in a comparison using a large number of unrelated higher plant species that, as expected, the mean DNA content for annual species $(21 \cdot 0 \mathrm{pg})$ was significantly lower than for perennial species (74.0 pg). Thus, the present results for Ranunculus species showing significantly higher DNA amount in perennials than in annuals agree with the findings published previously (Bennett, 1972). Moreover, the present results provide a striking example of closely related species which have considerably lower mean and maximum DNA amounts in annuals than in related perennials. As noted in the introduction, similar results were found in comparisons of related species in two other dicot genera, namely Lathyrus (Rees and Hazarika, 1969) and Vicia (Chooi, 1971).

It should of course be noted that other examples have been found in which the DNA contents of annual species exceeded that of related perennial species. For instance, Jones and Rees (1967) found that the DNA amounts of three annual Lolium species exceeded that of three perennial species (table 3). Both Nagl (1974), working on species in the tribe Anthemideae, 
and Kadir (1974), working on the genus Phalaris, noted that the DNA amounts of some perennial species were lower than those of annual species in the same genera. However, none of these findings are contrary to the expectations of the model proposed by Bennett $(1972,1973)$ demonstrating a positive relation between minimum generation time and DNA amount in higher plants.

The minimum generation time (m.g.t.) for a species is the shortest time in which it can produce mature seed after germination. As DNA amount increases, so also does m.g.t. and, therefore, the range of possible life-cycle types is progressively reduced. Each species can display any generation time equal to, or exceeding the m.g.t. determined by its DNA amount. Thus, species with very low DNA amounts can and do display the whole range of life-cycle types from ephemeral to long-lived perennial. Species with slightly higher DNA amounts cannot be ephemeral but may display annual, biennial or long-lived perennial life-cycles. Some species have DNA amounts so high that their m.g.t. equals or exceeds 52 weeks. By definition, such species cannot be annuals. Perenniality in such species is not genetically determined, but is dictated by the physical properties of the nucleus, defined as the nucleotype (Bennett, 1972, 1973). Thus, species with DNA amounts so high that they preclude a m.g.t. of less than 52 weeks are nucleotypically determined "obligate perennials" (Bennett, 1972). Perenniality in species whose DNA amounts are not high enough to preclude a m.g.t. of less than 52 weeks is genetically determined. Such species may be subdivided into two types. First, there are those perennial species which set seed in their first growing season (e.g. Antirrhinum majus) and hence normally have m.g.t.'s equivalent to those of annuals. Such species have been termed "facultative perennials" (Bennett, 1972). Second, there are those perennial species which do not set seed in their first year of growth (e.g. Acer pseudoplantanus). Such species may be termed genetically determined obligate perennials. The DNA amount which determines a m.g.t. of 52 weeks, and hence precludes species with higher DNA amounts from displaying the annual life-cycle time, is unknown. In practice it must vary between different environments, being much higher in warm temperate climates with long growing seasons than in sub-arctic climates with very short growing seasons. In a comparison of 271 herbaceous angiosperm species the maximum $4 C$ DNA amount for an annual dicot was $59 \mathrm{pg}$ (Vicia faba) and for a monocot $110 \mathrm{pg}$ (octoploid Triticale): all 43 species with DNA amounts of 90 picograms or higher were perennials, and most if not all of these were probably nucleotypically determined obligate perennials. It seems extremely unlikely that any of the perennial Ranunculus species examined in the present work are nucleotypically determined obligate perennials, as they all had $4 C$ DNA amounts of $38.4 \mathrm{pg}$ or less, that is well below the maximum DNA amount known for an annual diploid dicot species (59 pg-in $V . f a b a)$.

In practice the ranges of DNA amounts known for facultative perennials and annuals are both essentially the same. For instance, the ranges of $3 C$ DNA amounts for diploid facultative perennial monocots and annual monocots were $4 \cdot 7-28 \cdot 6$ and $4 \cdot 3-28 \cdot 4 \mathrm{pg}$ respectively (Bennett, 1972). It follows, therefore, that some individual annual species have higher DNA amounts than some facultative perennials. Similarly, the mean DNA content for annual species may be significantly higher than the mean for 
facultative perennials, due to sampling error alone, especially when only very small samples of species are compared. It is worth noting, therefore, that in all three instances listed above in which the mean DNA amount for annual species was higher than the mean DNA amount in related perennials (i.e. in Lolium, Phalaris and Anthemideae), the comparison involved annual and facultative perennial species. Moreover, in each case, only a small sample of species was compared.

\section{TABLE 4}

The numbers of annual and perennial species whose 3C DNA amounts fall in successive 10 or 20 picogram increments of DNA amounts, showing the trend to perenniality with increasing DNA amount

$\begin{array}{ccccc}\text { Plant group } & \begin{array}{c}\text { Range of } \\ \text { DNA amounts } \\ (\mathrm{pg})\end{array} & \begin{array}{c}\text { Number of } \\ \text { annual } \\ \text { species }\end{array} & \begin{array}{c}\text { Number of } \\ \text { perennial } \\ \text { species }\end{array} & \begin{array}{c}\text { Perennials } \\ \%\end{array} \\ \text { Monocots } & 0-20 & 28 & 10 & 26 \cdot 5 \\ & 21-40 & 23 & 31 & 57 \cdot 4 \\ & 61-60 & 7 & 16 & 69 \cdot 6 \\ & 61-80 & 0 & 11 & 100 \cdot 0 \\ & 81-100 & 1 & 4 & 80 \cdot 0 \\ & 101-120 & 0 & 8 & 100 \cdot 0 \\ & 121-140 & 0 & 4 & 100 \cdot 0 \\ & 141-160 & 0 & 4 & 100 \cdot 0 \\ \text { Dicots } & 161 \text { or more } & 0 & 24 & 100 \cdot 0 \\ & & & & \\ & 0-10 & 22 & 17 & 43 \cdot 6 \\ & 11-20 & 7 & 8 & 53 \cdot 3 \\ & 21-30 & 13 & 13 & 50 \cdot 0 \\ & 31-40 & 1 & 7 & 87 \cdot 5 \\ & 41-50 & 1 & 4 & 80 \cdot 0 \\ & 51-60 & 0 & 4 & 100 \cdot 0 \\ & 61 \text { or more } & 0 & 3 & 100 \cdot 0\end{array}$

N.B.-3C DNA amounts for 271 species taken from Bennett, 1972.

Species whose perenniality is genetically determined presumably benefit from being able to postpone the later stages of their cycle to a growing season subsequent to that in which germination occurs. This ability might be expected to have increasing adaptive significance as the DNA amount precluding an annual life-cycle type is approached. This is because the chance of failing to produce fertile seed in unfavourable years is increased in annuals with high DNA amounts, whose m.g.t. is close to the duration of the growing season in a normal year. Thus, among species other than nucleotypically determined obligate perennials, as DNA amount increases, an increased tendency for species to display a perennial life type rather than an annual life type is expected. Analysis of the DNA amounts for 271 herbaceous species listed by Bennett (1972) shows that this expectation is fulfilled. In both dicot and monocot species the proportion of perennial species increases steadily with increasing DNA amount over the range of DNA amounts known for annuals (table 4). For instance, the range of DNA values of annual monocots is $4 \cdot 3-82.7 \mathrm{pg}$. Of the monocot species with DNA amounts below $20 \mathrm{pg}$, only 23 per cent were perennials, but the proportion of perennials among species with DNA amounts of 21-40, 41-60 and $61-80$ pg was about 57,70 and 100 per cent respectively. 
For species with very high DNA amounts the perennial life-cycle is obligatory, but, whether species with lower DNA amounts are annuals or perennials is subject to genetic control. The evidence presented above indicates that the genotype controls a perennial rather than an annual lifecycle type more often in species with high DNA amounts than in species with low DNA amounts. The result of this trend to perenniality with increasing DNA amount means that, overall, the mean DNA content of genetically determined perennial species is higher than the mean for annuals. It should be noted that, for samples of species all with low DNA amounts, the correlation of the perennial life type with higher nuclear DNA amount is not expected to be pronounced and may often be absent or undetected, especially when only small samples of species are compared. However, the correlation should become more obvious as the maximum DNA amount of the sample of species being compared is increased. The data for six groups of plants given in table 3 illustrate this point. Thus, in the three groups of plants with maximum DNA amounts of 28 picograms or less (Phalaris, Anthemideae and Lolium) the mean DNA content for annuals was higher than for perennials, while in the three groups of plants with maximum DNA amounts of 28 picograms or more (Lathyrus, Ranunculus and Vicia), the converse was true.

\section{REFERENCES}

Ayonoadu, U. w. U. 1974. Nuclear DNA variation in Phaseolus. Chromosoma (Berl.), 48, 41-49.

BENNETT, M. D. 1972. Nuclear DNA content and minimum generation time in herbaceous plants. Proc. Roy. Soc. Lond. B., 181, 109-135.

BENNETT, M. D. 1973. Nuclear characters in plants. Brookhaven Symp., 25, 344-366.

BENNETT, M. D., AND SMrTH, J. B. 1971. The $4 C$ DNA content of several Hordeum genotypes. Can. F. Genet. Cytol., 13, 607-611.

BULlen, M. R., AND REEs, H. 1972. Nuclear variation within Avenae. Chromosoma (Berl.), $39,93-100$.

CHoor, w. Y. 1971. Variation in nuclear DNA content in the genus Vicia. Genetics, 68, 195-211.

Commoner, B. 1964. Roles of desoxyribonucleic acid in inheritance. Nature (Lond.), 202, 960-968.

EDWARDS, G. A., ENDRIZZI, J. E., AND STEIN, R. 1974. Genome DNA content and chromosome organisation in Gossypium. Chromosoma (Berl.), 47, 309-326.

FURUTA, Y. 1970. DNA content per nucleus in Aegilops species. Wheat Inf. Serv. Kyoto Univ., 30, 20-22.

INGLE, J., AND SINCLAIR, J. 1972. Ribosomal RNA genes and plant development. Nature (Lond.), 235, 30-32.

JONES, G. H., AND REES, H. 1967. Chromosome evolution in Lolium. Heredity, 20, 1-18.

JONES, R. N., AND REES, H. 1968. Nuclear DNA variation in Allium. Heredity, 23, 591-605. KADIR, z. B. A. 1974. DNA values in the genus Phalaris (Gramineae). Chromosoma (Berl.), 45, 379-386.

MCLEISH, J., AND SUNDERLAND, N. 1961. Measurements of desoxyribonucleic acid (DNA) in higher plants by Feulgen photometry and chemical methods. Expl. Cell Res., 24, 527-540.

NAGL, w. 1974. Role of heterochromatin in the control of cell cycle duration. Nature (Lond.), 249, 53.

NARAYAN, R. K., AND REEs, H. 1974. Nuclear DNA, heterochromatin, and phylogeny of Nicotiana amphidiploids. Chromosoma (Berl.), 47, 75-83.

PARODA, R. S., AND REES, H. 1971. Nuclear DNA variation in Eu-Sorghums. Chromosoma (Berl.), 32, 353-363.

REEs, H., AND HAZARIKA, M. H. 1969. Chromosome evolution in Lathyrus. Chromosomes Today 2, 158-165. Oliver \& Boyd, Edinburgh. 
ROthfels, K., SEXSmith, E., heimburger, M., Afd krause, M. o. 1966. Chromosome size and DNA content of species of Anemone L. and related genera (Ranunculaceae). Chromosoma (Berl.), 20, 54-74.

southern, D. I. 1967. Species relationships in the genus Tulipa. Chromosoma (Berl.), 23, 80-94.

SPARROW, A. H., AND NAUMAN, A. F. 1973. Evolutionary changes in genome and chromosome sizes and in DNA content in the grasses. Brookhaven Symp., 25, 367-389.

VERMA, s. c., AND REES, H. 1974. Nuclear DNA and the evolution of allotetraploid Brassicae. Heredity, 33, 61-68. 